\title{
Exposure to Floods, Climate Change, and Poverty in Vietnam
}

\author{
Mook Bangalore ${ }^{1,2} \cdot$ Andrew Smith ${ }^{3} \cdot$ Ted Veldkamp ${ }^{4,5}$ \\ Received: 16 February 2018 / Accepted: 4 October 2018/Published online: 26 October 2018 \\ (C) The Author(s) 2018
}

\begin{abstract}
With $70 \%$ of its population living in coastal areas and low-lying deltas, Vietnam is highly exposed to riverine and coastal flooding. This paper conducts a "stress-test" and examines the exposure of the population and poor people in particular to current and future flooding in Vietnam and specifically in Ho Chi Minh City. We develop new high-resolution flood hazard maps at $90 \mathrm{~m}$ horizontal resolution, and combine this with spatially-explicit socioeconomic data on poverty at the country and city level, two datasets often kept separate. The nationallevel analysis finds that a third of today's population is already exposed to a flood, which occurs once every 25 years, assuming no protection. For the same return period flood under current socioeconomic conditions, climate change may increase the number exposed to 38 to $46 \%$ of the population (an increase of 13-27\% above current exposure), depending on the severity of sea level rise. While poor districts are not found to be more exposed to floods at the national level, the city-level analysis of Ho Chi Minh City provides evidence that slum areas are more exposed than other urban areas. The results of this paper provide an estimate of the potential exposure under climate change, including for poor people, and can provide input on where to locate future investments in flood risk management.
\end{abstract}

JEL Codes Q54 $\cdot \mathrm{I} 30 \cdot \mathrm{Q} 50$

Keywords Floods $\cdot$ Poverty $\cdot$ Vietnam $\cdot$ Exposure $\cdot$ Urban development

Electronic supplementary material The online version of this article (https://doi.org/10.1007/s41885-0180035-4) contains supplementary material, which is available to authorized users.

Mook Bangalore

M.Bangalore@1se.ac.uk

1 Grantham Research Institute and Department of Geography and Environment, London School of Economics, London WC2A 2AE, UK

2 World Bank, Washington, DC, USA

3 Fathom, Bristol, UK

4 Institute for Environmental Studies, Vrije Universiteit, Amsterdam, Netherlands

5 Water Department, International Institute for Applied Systems Analysis (IIASA), Laxenburg, Austria 


\section{Introduction}

Vietnam is a rapidly developing country highly exposed to natural hazards. One of the major natural hazards the country faces is riverine and coastal flooding, due to its topography and socioeconomic concentration: Vietnam's coastline is $3200 \mathrm{~km}$ long and $70 \%$ of its population lives in coastal areas and low-lying deltas (GFDRR 2015). Furthermore, climate change is expected to increase sea level and the frequency and intensity of floods, globally and in Southeast Asia (IPCC 2014; World Bank 2014). Given the country's concentration of population and economic assets in exposed areas, Vietnam has been ranked among the five countries most affected by climate change: a $1 \mathrm{~m}$ rise in sea level would partially inundate $11 \%$ of the population and $7 \%$ of agricultural land (World Bank and GFDRR 2011; GFDRR 2015).

Even though climate change impacts are expected to primarily occur in the future, flooding already causes major problems in Vietnam, with some segments of the population more vulnerable than others (Adger 1999; World Bank 2010; World Bank and Australian AID 2014). In particular, evidence suggests poor people are more vulnerable than the rest of the population to natural disasters such as floods, as their incomes are more dependent on weather, their housing and assets are less protected, and they are more prone to health impacts (Hallegatte et al. 2016, Chapter 3). Poor people also have a lower capacity to cope with and adapt to shocks due to lower access to savings, borrowing, or social protection; and climate change is likely to worsen these trends (Hallegatte et al. 2016, Chapter 5).

Therefore, it is important to quantify how many people are exposed to floods, how this distribution of exposure falls upon regions and socioeconomic groups, and how climate change may influence these trends. In the spirit of a "stress-test" to examine the seriousness of the issue, this paper employs flood hazard maps and spatial socioeconomic data to examine the following questions in context of Vietnam:

1. How many people are exposed currently? How might this change under climate change?

2. Where is exposure highest currently? How might this change under climate change?

3. How many poor people are exposed currently? How might this change under climate change?

Furthermore, given that the dynamics of poverty and natural disasters (and particularly, floods) occur at the local level, analyses at the national scale (or even at the province or district level) may miss important mechanisms and small-scale differences, from one city block to the next. To complement the country-level analysis, we also focus at the local level within Ho Chi Minh City (HCMC), a city with high flood exposure. Here, we combine high-resolution flood hazard data with spatial data on slum location to examine the distribution of exposure across poor and non-poor locations.

While prior studies have examined flood risk in Vietnam, this paper provides two main contributions. First, we develop new high-resolution flood hazard datasets, which incorporate both riverine and coastal flooding and consider climate change. ${ }^{1}$ When examining flood exposure, it is important to get as local as possible as impacts can vary widely across space - for instance, impacts can be different from one city block to the next (Patankar 2015). This

\footnotetext{
${ }^{1}$ Prior use hazard data at a $1 \mathrm{~km}$ resolution and are restricted to a single district or city within Vietnam (Chinh et al. 2017; Apel et al. 2016). We develop new high-resolution flood hazard datasets on a $90 \mathrm{~m} \times 90 \mathrm{~m}$ grid.
} 
paper contributes to the growing literature in economics on the assessment of local and disaggregated disaster impacts (e.g. Del Valle et al. 2018 using wind speed), and is the first to our knowledge examining flood risk at this scale in a developing country.

Second, we analyze how flood exposure differs based on socioeconomic dimensions, in this case poverty, at the country and city-level. In both cases, we examine how flood exposure and poverty differs spatially across the country (at the district level) but also within HCMC (by identifying slums). The combination of these two datasets on hazard and poverty - typically kept separate in the literature - is another main contribution of this paper.

The consideration of socioeconomic characteristics and the focus on the poor is an important one as not all segments of the population are equally exposed and vulnerable to floods. In some cases, people living in risky places may be richer than the average population: for instance, urban residents are on average wealthier than those living in rural areas (World Bank 2009). At a more local scale and especially within cities, land and housing markets often push poorer people to settle in riskier areas: where markets factor in hazard risks, housing is cheaper where risk is higher, attracting poorer segments of the population (Husby and Hofkes 2015; Lall and Deichmann 2012).

In addition to differentiated exposure, poor people have higher vulnerabilities: for the same level of losses (e.g. \$100), impacts on poor people are much more pronounced than those on richer segments of the population. This poverty-vulnerability relationship operates through the asset, income, and consumption channels. In terms of assets, oftentimes the portfolio of poor people's assets is concentrated in livestock and housing which are vulnerable to floods (Barrett et al. 2013). In comparison, non-poor people tend to have larger amounts of their assets in financial forms (e.g. savings in a bank). Regarding income losses, poor people are more likely to have less diversified income sources (e.g. with income streams reliant on vulnerable assets such as livestock). In comparison, non-poor people's income sources are often more diversified (e.g. including from pensions, capital gains, or remittances). As these income sources are often unaffected by a local flood event, income losses for non-poor people may be less pronounced (Hallegatte et al. 2017).

Poor people may also take longer to recover from a flood event due to a limited ability to smooth the shock with limited access to insurance, fewer savings, and limited borrowing capacity. While government support can help after a flood, such support may be inadequate particularly in developing countries with limited technical and financial capacity. In Mumbai, while government support existed after the 2005 floods, it was slow to arrive and the amount delivered was inadequate to support losses suffered (Patankar 2015). Given that poor people have consumption closer to subsistence, a substantial loss from floods in the absence of support can have high non-monetary costs in the form of irreversible impacts on children and distress sales of assets (de Janvry et al. 2006; World Bank and Australian AID 2014). In summary, livelihood shocks triggered by floods could keep people from escaping poverty and even push them into deeper poverty (Karim and Noy 2014).

Despite this poverty-vulnerability relationship, previous quantitative studies on flood exposure in Vietnam have focused on the generation of losses rather than exposure across socioeconomic levels (Chinh et al. 2017; Apel et al. 2016; MONRE 2009). Nevertheless, insights from qualitative focus groups across the country (in An Giang, Kien Giang, Kon Tum, Hoa Binh, and Bac Nih) find that many poor households feel more vulnerable to floods due to their increased exposure (a result of living in flood prone areas, like along river banks or outside of protective dikes, and often having substandard quality of housing) are less likely to have sufficient assets to buffer the effects of floods, and receive inadequate support to cope (World Bank 2016). 
This paper provides an in-depth case study of floods, poverty, and climate change in Vietnam and Ho Chi Minh City, examining the exposure of the total population, and poor people in particular to current and future flood hazards, to better understand the problem. While we do not conduct a full probabilistic risk assessment simulating all current and future parameters (which would be extremely challenging), we conduct a stress test to examine how future exposure to floods might look like if current population and poverty trends stay the same.

We find at the national-level that a third (33\%) of today's population is already exposed to a 25 year event, assuming no protection. For the same return period flood under current socioeconomic conditions, climate change may increase the number exposed to 38 to $46 \%$ of the population (an increase of 13-27\% above current exposure), depending on the severity of sea level rise. While poor districts are not found to be more exposed to floods at the national level, the city-level analysis of HCMC provides evidence that $68-85 \%$ of slum areas are exposed to floods, a higher percentage than the rest of the city. The results of this paper provide an assessment of current and future exposure levels, and can provide input on where to locate future investments in flood risk management.

Given these potentially large impacts, a key question of importance to public policy is what is the level of adaptive capacity for households, and whether there are any trade-offs between public response and private preparation particularly in a developing country setting (Goeschl and Managi 2017). For rural households, recently the Vietnamese Government has increased efforts to improve adaptive capacity and farmers have started to shift cropping patterns (Thoai et al. 2018). However, farmers still have limited understanding of the importance of climate adaptation for their livelihoods and there is a need for better government aid after flood events (Le Dang et al. 2014; McElwee et al. 2017). In urban areas, private adaptive capacity may be even lower, resulting in an increasing need for urban planning to incorporate climate risk dimensions (Liao et al. 2016). While adaptation is not a focus of this paper, the uncertain and growing impacts of flood risk found in this paper indicate more attention is warranted to design effective adaptation policies.

\section{Data}

To examine population and poverty-specific exposure to floods, we employ spatial data defining flood hazard and a number of socioeconomic characteristics representing poverty and population density.

\section{Flood Hazard Data}

\section{Flood Hazard Maps for Vietnam Developed for this Study}

For this study, we developed flood hazard maps representing riverine, flash-flood and coastal flood hazards for Vietnam. These flood hazard maps estimate the inundation depth at a grid cell level of 3 arc-seconds, $(\sim 90 \mathrm{~m})$ and provide coastal surge hazard layers, along with pluvial and fluvial layers. The maps provide information on the extent and depth of flood hazard for a specific location. For the coastal component, we explicitly model four return periods - 25, 50, 100, and 200 year events, under current and future climate conditions. 
There is a significant amount of uncertainty with regard to how much sea level will rise. For that reason we model three future climate scenarios per return period: a low, medium, and high scenario (Table 1), using estimates from the IPCC (IPCC 2014; IPCC 2007). For the fluvial and pluvial hazards, future climate scenarios were not explicitly simulated owing to the complexity and considerable uncertainties that arise (Smith et al. 2014). ${ }^{2}$

Although robust modeling of the magnitude of future extreme rainfall is not yet possible, heavy rainfall is expected to increase in a warmer climate, owing to the increased water holding capacity of the atmosphere. Therefore instead of a direct modeling approach, future climate scenarios were inferred by taking flood hazard maps derived under current climate conditions for different return periods, and using them as a proxy for future climate scenarios. The return period hazard maps used for each of the future scenarios are outlined in Table 2. Although simplistic, this method allows areas that may be impacted by increasing riverine and extreme rainfall driven flooding to be identified. Clearly there are some significant assumptions and uncertainties arising from this method. However, given the impracticalities of modeling future flood hazard in Vietnam, this approach provides a plausible and practical attempt to estimate changing flood hazard at the national scale.

For each of the four return periods, four scenarios are modeled (historical, future with low sea level rise, future with medium sea level rise, and future with high sea level rise), combining the coastal and fluvial/pluvial hazard layers (Table 2). For full details on the methodology used to produce these hazard maps, see the online supplementary materials. Importantly, the flood hazard models do not include flood protection (such as dikes and drainage systems), which can make a large difference in the flood hazard particularly in well-protected areas. In these wellprotected areas, our flood maps may overestimate the flood hazard. This is a data limitation that affects many studies of flood exposure: even in high-income countries like the US, flood protection databases are incomplete and many areas are left undefended in national models when in reality they are defended (Wing et al. 2017). While recent work has tried to patch together a database of flood protection (Scussolini et al. 2016), the authors admit much remains unclear and this is a current state of the research.

For most of the analyses, the "combined" maps are used, which include both coastal and the fluvial/pluvial floods. For instance, the combined maps for the 25-year return period flood (under current conditions, and low, medium, and high future conditions) are presented in Fig. 1 .

\section{Local Flood Hazard Maps for Ho Chi Minh City}

In addition to the flood hazard maps developed for this study as described above, we use an additional set of maps produced specifically for HCMC.

\footnotetext{
${ }^{2}$ These uncertainties largely arise from climate models; global climate models (GCMs) struggle to represent the physical processes that produce extreme rainfall. Indeed even in higher resolution regional climate models (RCMs), heavy rainfall events are poorly represented. As a result the modeled rainfall data must be 'corrected', in order to render it realistic. The fact that the underlying models themselves cannot represent flood driving rainfall means that there is little confidence in the projections that they produce. Moreover, at the national scale there is very little river gauge data available in Vietnam. Therefore rainfall-runoff models, required to transform rainfall projections into river discharge values, would be largely un-calibrated. This adds an additional source of significant modeling uncertainty to the model cascade. The combination of poorly represented extreme rainfall in climate models, coupled with uncalibrated rainfall-runoff models, would largely render any projections of future flood hazard impractical, owing to the significant uncertainties that arise.
} 
Table 1 Future scenarios used for Vietnam coastal modeling. RCP stands for Representative Concentration Pathway. We use two RCPs from the recent Intergovernmental Panel on Climate Change (IPCC) report (IPCC 2014) to represent a low climate change and a high climate change scenario. RCP2.6 is a low scenario consistent with temperature increases of $2{ }^{\circ} \mathrm{C}$, while RCP8.5 is a high scenario consistent with temperature increases of $4{ }^{\circ} \mathrm{C}$. The A1B scenario was taken from a previous IPCC report (IPCC 2007) and represents a medium climate change scenario, in between RCP2.6 and RCP8.5

\begin{tabular}{llll}
\hline Simulations & Scenario & Percentile & SLR -2100 (m) \\
\hline Low & RCP 2.6 & 0.5 & 0.28 \\
Medium & A1B & 0.05 & 0.6 \\
High & RCP 8.5 & 0.95 & 0.98 \\
\hline
\end{tabular}

The inundation maps were used in an earlier flood risk study of HCMC (Lasage et al. 2014), and were composed with the MIKE 11 hydraulic modeling software (DHI 2003). The flood hazard maps, which have a spatial resolution of $20 \mathrm{~m}$, represent the current conditions for five return periods: $10,25,50,100$, and 1000 years. Future conditions, again using the five return periods, include a sea level rise scenario of $+30 \mathrm{~cm}$ in the year 2050 (consistent with the "low" sea level rise used for the maps produced for this study) in combination with current river discharge (FIM 2013). Potential peaks in precipitation events and/or river discharges due to climate change are not covered by this data set. The inundation layers for a 10, 25, and 50year return period under current climate conditions and given a sea level rise scenario of $+30 \mathrm{~cm}$ are shown in Fig. 2 .

\section{Socioeconomic Data}

\section{District-Level Poverty and Population Data}

At the national-level analysis, we overlay the flood hazard maps developed for this study with spatial socioeconomic data. For Vietnam, the World Bank has produced estimates of the

Table 2 Hazard map scenarios for which the modeling was conducted for Vietnam

\begin{tabular}{lll}
\hline Scenario & Coastal & Fluvial/Pluvial \\
\hline 1 in 25 & 1 in 25 & 1 in 25 \\
1 in 25 Future - Low & 1 in $25+28 \mathrm{~cm}$ & 1 in 50 \\
1 in 25 Future - Medium & 1 in $25+6 \mathrm{~cm}$ & 1 in 75 \\
1 in 25 Future - High & 1 in $25+98 \mathrm{~cm}$ & 1 in 100 \\
1 in 50 & 1 in 50 & 1 in 50 \\
1 in 50 Future - Low & 1 in $50+28 \mathrm{~cm}$ & 1 in 75 \\
1 in 50 Future - Medium & 1 in $50+6 \mathrm{~cm}$ & 1 in 100 \\
1 in 50 Future - High & 1 in $50+98 \mathrm{~cm}$ & 1 in 200 \\
1 in 100 & 1 in 100 & 1 in 100 \\
1 in 100 Future - Low & 1 in $100+28 \mathrm{~cm}$ & 1 in 200 \\
1 in 100 Future - Medium & 1 in $100+6 \mathrm{~cm}$ & 1 in 250 \\
1 in 100 Future - High & 1 in $100+98 \mathrm{~cm}$ & 1 in 500 \\
1 in 200 & 1 in 200 & 1 in 200 \\
1 in 200 Future - Low & 1 in $200+28 \mathrm{~cm}$ & 1 in 250 \\
1 in 200 Future - Medium & 1 in $200+6 \mathrm{~cm}$ & 1 in 500 \\
1 in 200 Future - High & 1 in $200+98 \mathrm{~cm}$ & 1 in 1000 \\
\hline
\end{tabular}




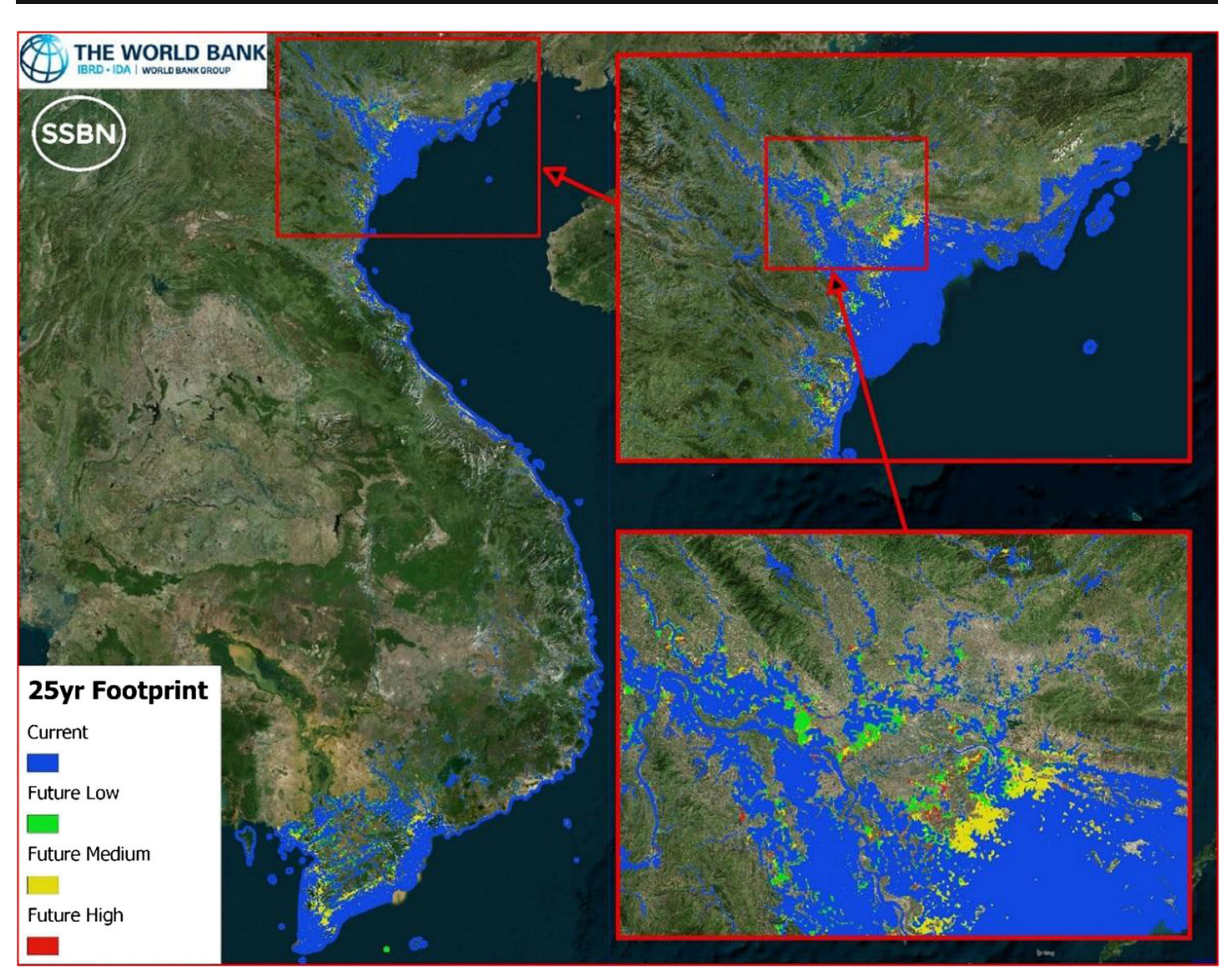

Fig. 1 A visual of what the combined hazard maps (which include coastal and fluvial/pluvial) look like. The map presented here is the worse-case scenario we simulate, a 200-year return period flood with high sea level rise

number of people within each district who live below the poverty line: this "poverty map" is displayed in Fig. 3a, and the full methodology can be found in (Lanjouw et al. 2013). ${ }^{3}$ In addition, we use gridded population density data with a $1 \mathrm{~km}$ resolution from Landscan (Geographic Information Science and Technology 2015). This "population map" is displayed in Fig. 3b.

While we are able to simulate current and future flood hazard, we are unable to project socioeconomic characteristics like poverty or population at the district level, as such an exercise is extremely challenging. Specifically for Vietnam, a recent paper models population and poverty in 2030 at national-level, but notes that examining how these dynamics is distributed spatially within the country is still not possible (Rozenberg and Hallegatte 2016). Nonetheless, as a stress test, a number of papers in the field have employed the same strategy we follow in this paper, of using current socio-economic characteristics to examine potential future trends, which is considered standard practice (Hirabayashi et al. 2013; Koks et al. 2015; Winsemius et al. 2015).

\footnotetext{
${ }^{3}$ While we considered other metrics of poverty (e.g. the Multi-dimensional Poverty Index), the only available data that was spatially explicit was the headcount and headcount rate, which we use for the analysis. This headcount rate uses an income definition of poverty, with those earning less than \$1.25 USD per day classified as poor.
} 
(a) Current Cond - RP 1/10 years

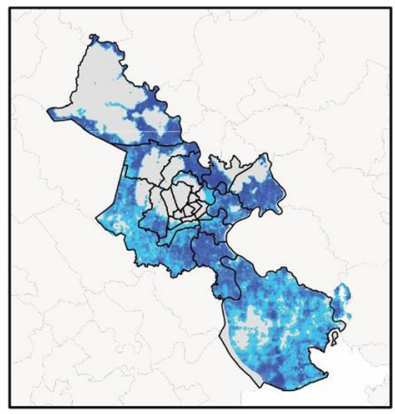

(d) Future Cond $+30 \mathrm{~cm}$ SLR - RP 1/10 years

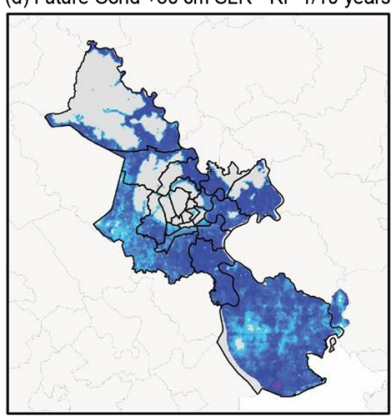

Inundation depth $(\mathrm{cm})$ (b) Current Cond - RP 1/25 years

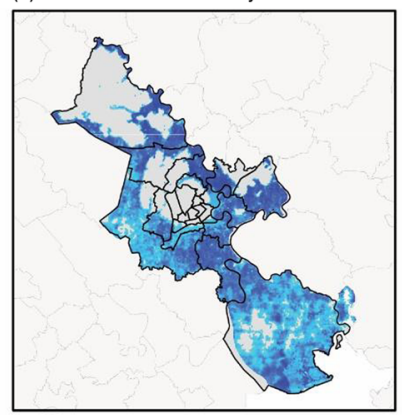

(e) Future Cond $+30 \mathrm{~cm}$ SLR - RP 1/25 years

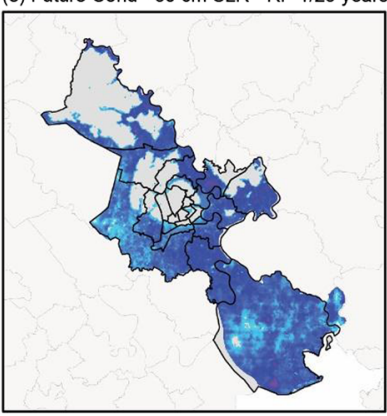

(c) Current Cond - RP 1/50 years

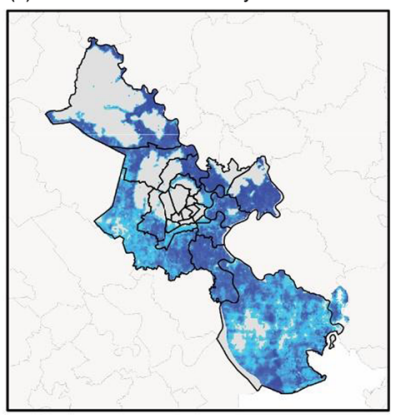

(f) Future Cond $+30 \mathrm{~cm}$ SLR - RP 1/50 years

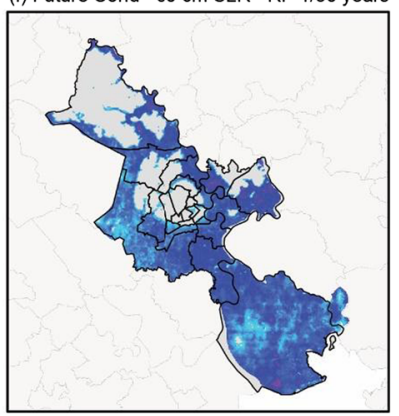

Fig. 2 Flood maps showing inundation depth (cm) in case of a: (a) 10-year return period flood under current conditions, (b) 25-year return period flood under current conditions; (c) 50-year return period flood under current conditions; (d) 10-year return period flood given a $30 \mathrm{~cm}$ sea level rise; (e) 25-year return period flood given a $30 \mathrm{~cm}$ sea level rise; and (f) 50 -year return period flood given a $30 \mathrm{~cm}$ sea level rise

\section{Local-Level Data on Urban Areas and Potential Slums in Ho Chi Minh City}

The spatial socioeconomic data set used for HCMC is a data set of potential slum areas from 2000 to 2010, from the Platform for Urban Management and Analysis (PUMA), a city-level data set developed by the World Bank (World Bank 2015).This data was collected via satellite in the year 2012, through a combination of visual interpretation of various sources and vintages of imagery.

To guide the identification of slums, previous work has provided information on the appearance and geographical extent of slums in HCMC. Surveys of poverty in the city find the appearance of slums in HCMC to be characterized as densely built small households and shelters that have predominantly semi-permanent character (Habitat for Humanity 2008). In terms of geographic extent, many slums are located in certain districts (districts 2, 3, 4, 6, 8, 11, 12, Binh Thanh, Go Vap, Tan Phu) and along the Saigon River (e.g. Kenh Te, Rach Ben Nghe, Thi NgheNhieu Loc Canal, Kenh Doi, Thi Nghe Canal, Lo Gom, and Canala) (Horsley 2004; De Lay 2011; Habitat for Humanity 2008). Taking into account these spatial and geographic characteristics, the PUMA data set interprets Google Earth imagery to produce two layers of potential slum areas (PUMA 2013): areas with defined borders (polygon-data) and potential slum areas without (point-data) defined borders. In the latter case, we applied a circular buffer of $50 \mathrm{~m}$ around each 

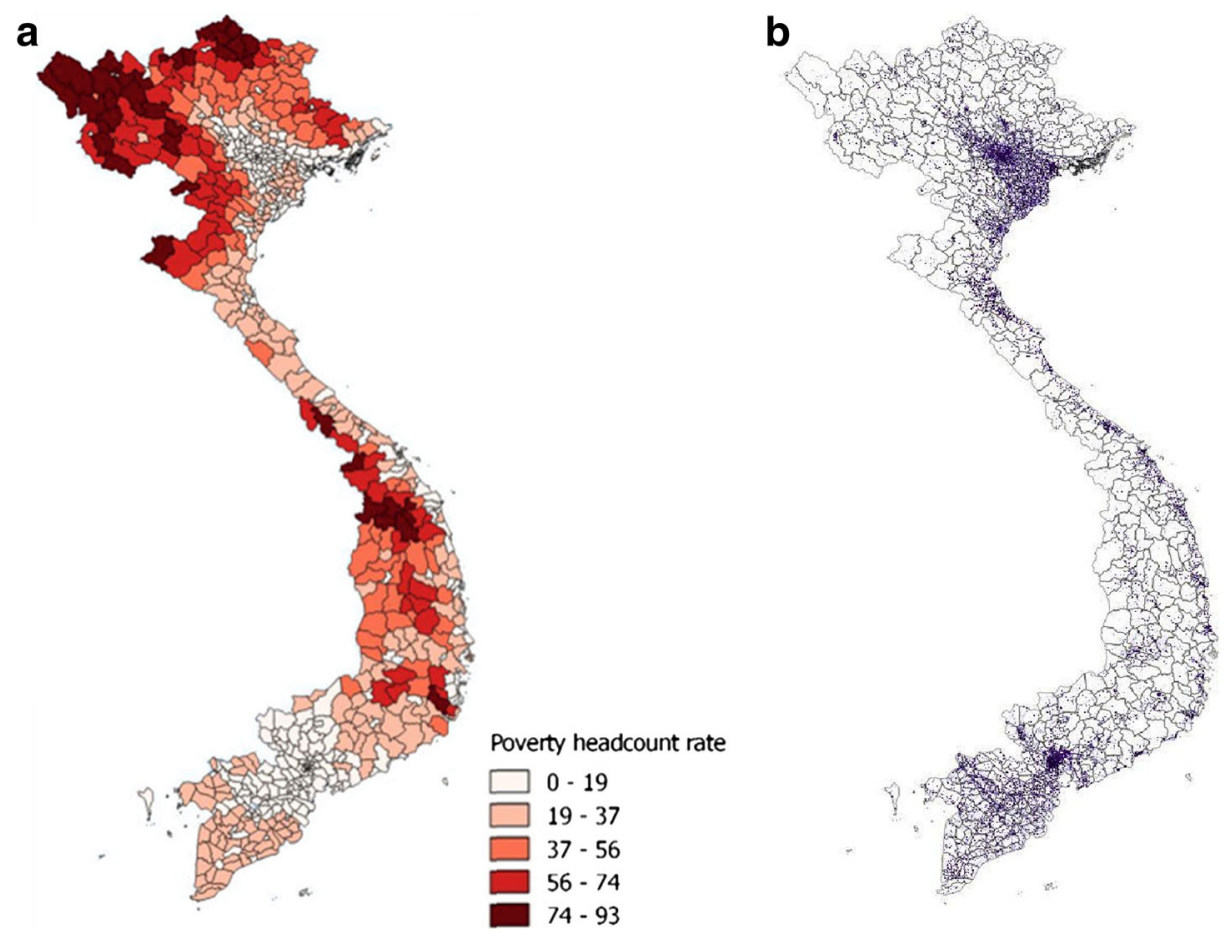

Fig. 3 (a) Poverty map and (b) population density map for Vietnam at the district level. Sources: (Lanjouw et al. 2013; Geographic Information Science and Technology 2015)

point indicating a potential slum location. Evidence suggests that slum areas exist in the northern districts of HCMC (Habitat for Humanity 2008), which we do not find in PUMA. For this reason, we ran the analyses for two samples - all the districts in the province, and only the districts with potential slums from PUMA. The potential slum locations are presented in Fig. 4.

\section{Methodology}

\section{Exposure to Flooding at the National Level}

At the national level, we estimate per district the number of people exposed to each scenario of flooding, and the number of poor people exposed. In the flood data, we define exposed areas as those grid cells where the flood level is greater than zero; non-exposed areas are those grid cells where the flood level is zero. This is a measure of extent rather than depth, and has been used in previous studies to examine exposure to floods (Jongman et al. 2014; Winsemius et al. 2015; Ceola et al. 2014). Furthermore, while we lose information by using extent rather than depth (we have depths in our flood data), we decided to use extent since our flood data assumes no protection. Protection is more likely to impact the depth, rather than the extent, of the flood results. ${ }^{4}$

\footnotetext{
${ }^{4}$ There is also a good reason for examining extent over depth, in terms of the hazard modeling; flood depths within a large scale flood model are very uncertain, and there is much more certainty about extents.
} 

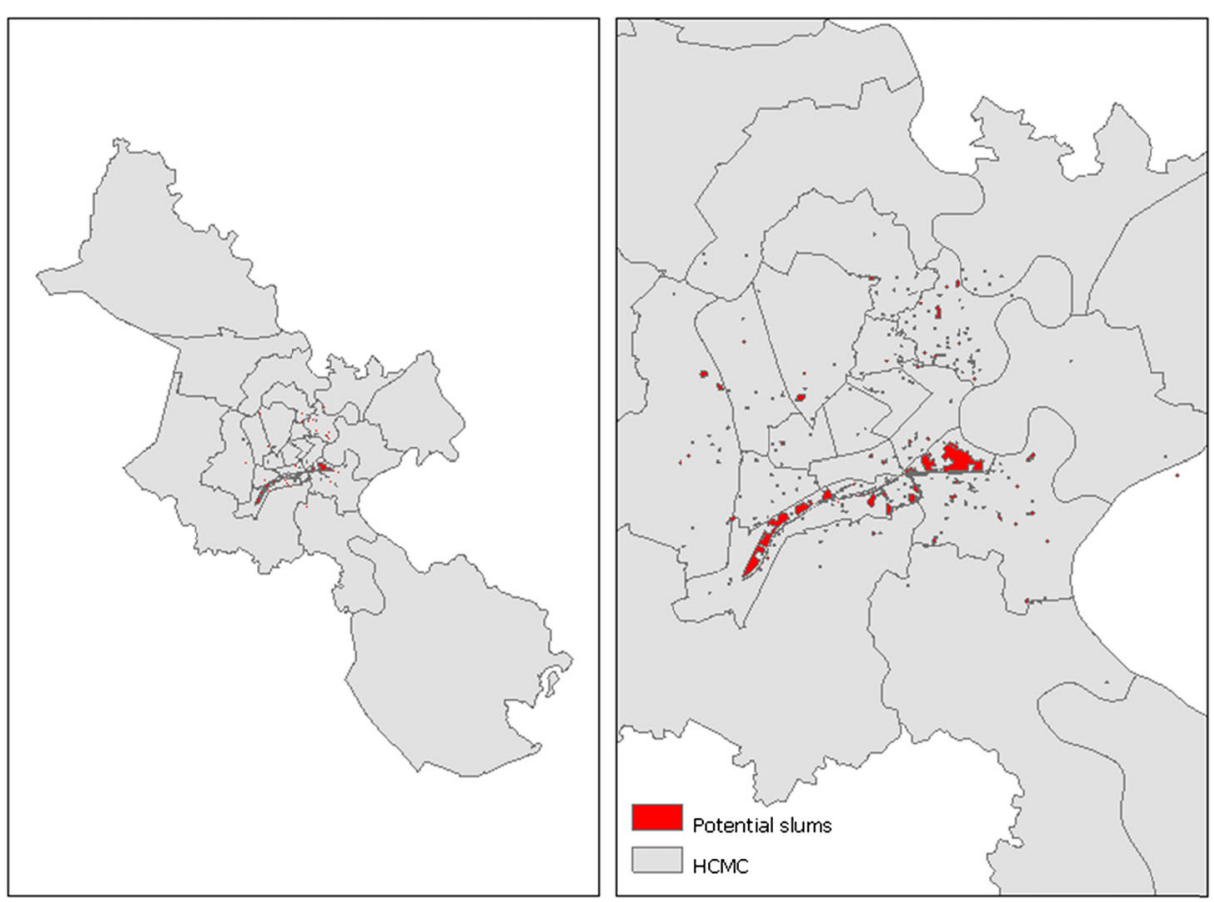

Fig. 4 Location of slum areas and locations with urban expansion in the city of HCMC. Source: (PUMA 2013)

We then overlay this flood layer with the population density data set, to estimate the number of people per population grid cell that are exposed to floods. As the population density data set is at a lower resolution $(1 \mathrm{~km})$ than the flood data $(90 \mathrm{~m})$, we estimate the percentage of the population grid cell which is flooded, and multiply this percentage by the population in that grid cell. For instance, if a population grid cell has 500 people, and $10 \%$ of that cell is flooded (based on the flood data), then we estimate 50 people to be exposed to floods in that cell. In doing so, we assume that the population is evenly distributed within a grid cell.

We run this analysis for all the scenarios presented in Table 2, and aggregate our results at the district level to estimate the number of people affected. To include the poverty dimension, we use the poverty headcount rate in each district to estimate the percentage of poor people exposed. For instance, if 20,000 people are exposed to floods in District X, and District X has a poverty headcount rate of $20 \%, 1000$ poor people are exposed to floods in that district. $^{5}$

\section{Slum Exposure in Ho Chi Minh City}

For the HCMC analysis, we estimate the general exposure to flooding, for the whole province of HCMC and in each of its 24 districts. The flood maps used here are based on a model of $\mathrm{HCMC}$, and are not the same map as used in the figurative example in Section 4.1.

\footnotetext{
${ }^{5}$ As evidenced in the HCMC analysis with slum data, poor people are often not evenly distributed but clustered in particular areas. However, due to data limitations across the country, we assume poverty is evenly distributed within a district when conducting the national-level analysis.
} 
Exposure to flooding was again evaluated using flood extent (we also evaluate flood depth, for full results, see online supplementary materials). We examine the flood extent both for all urban areas (the whole HCMC province) and for those areas defined as potential slums (from the PUMA data set) to examine how exposure to floods is different in slum areas.

Again we use a number of events, from the case of regular flooding (10-year event) to more extreme flooding events (1000-year event). Moreover, we examine how this exposure changes due to climate change (proxied by sea level rise changes), by running the analysis with flood hazard maps taking into account a $30 \mathrm{~cm}$ sea level rise. In each district and across the whole city, we examine the percentage of area within each of the two categories (all urban areas, and potential slum areas) that is exposed to floods and the percentage which is not exposed to floods. We then compare these values across the two categories.

\section{Results}

\section{National-Level Analysis for Poverty and Exposure to Floods}

\section{Flood Exposure (with and without Climate Change)}

For the entire country of Vietnam, at the district level, we estimate the total number of people and the share of the population who are exposed to floods. In the results presented, we examine the four scenarios for the 25-year, 50-year, 100-year and 200-year return period flood - a historical scenario, and three scenarios representing future climate: a low, medium, and high scenarios.

We aggregate the results at the country level. ${ }^{6}$ A third (33\%) of today's population is already exposed to a 25-year flood in Vietnam, assuming no protection (such as dikes and drainage systems), which can make a large difference in the flood hazard particularly in wellprotected areas. In these well-protected areas, our flood maps may over-estimate the flood hazard.

When including climate change, this percentage increases by $13-27 \%$, depending on the severity of sea level rise. This increase in exposure is due to the concentration of the population in coastal areas. For the 50-year flood, more than a third (38\%) of today's population is already exposed. Given climate change, this number is expected to increase by $7-21 \%$ (resulting in overall exposure of between 40 and $48 \%$ ) for the same return period (50-year). For a 100- and 200 -year flood under a high climate scenario, more than half of the population is exposed.

Climate change impacts can be seen in these exposure numbers - for instance, a 50-year flood with medium climate change impacts has the same exposure of a 200 -year historical flood (at 44\%), while almost half the country's population (48\%) is exposed to a 50-year flood with high climate impacts. Full results are presented in Table 3.

But these national results on exposure are not evenly be distributed across the country. The spatial analysis also allows us to examine which districts have the highest absolute and the highest relative exposure. We present results for the 25-year flood, for a historical and a high

\footnotetext{
${ }^{6}$ Results presented are similar to a previous study analyzing the exposure to a 100 -year return period flood without climate change impacts, which finds 40 million people to be exposed to that event (Jongman et al. 2014). While we had planned to compare our simulated results with national statistics, these statistics were unavailable at the time of analysis. However, we consulted our findings with individuals familiar with the Vietnam context who ended to agree that the numbers were in the range of plausible estimates.
} 
Table 3 Population exposed to floods in Vietnam, across the 16 flood hazard scenarios examined

\begin{tabular}{|c|c|c|c|c|c|}
\hline \multirow[t]{2}{*}{ Scenario } & \multirow[t]{2}{*}{ Exposure } & \multicolumn{4}{|c|}{ Return period } \\
\hline & & 25 & 50 & 100 & 200 \\
\hline \multirow[t]{2}{*}{ Historical } & Estimated population exposed (million) & 30.17 & 34.30 & 38.35 & 40.43 \\
\hline & Percentage of today's population & $33 \%$ & $38 \%$ & $42 \%$ & $44 \%$ \\
\hline \multirow[t]{3}{*}{ Low climate change } & Estimated population exposed (million) & 34.78 & 36.87 & 40.91 & 42.32 \\
\hline & Percentage of today's population & $38 \%$ & $40 \%$ & $45 \%$ & $46 \%$ \\
\hline & Increase due to climate change & $13 \%$ & $7 \%$ & $6 \%$ & $4 \%$ \\
\hline \multirow[t]{3}{*}{ Medium climate change } & Estimated population exposed (million) & 38.03 & 40.22 & 43.34 & 45.16 \\
\hline & Percentage of today's population & $42 \%$ & $44 \%$ & $48 \%$ & $50 \%$ \\
\hline & Increase due to climate change & $21 \%$ & $15 \%$ & $11 \%$ & $10 \%$ \\
\hline \multirow[t]{3}{*}{ High climate change } & Estimated population exposed (million) & 41.46 & 43.36 & 46.13 & 48.72 \\
\hline & Percentage of today's population & $46 \%$ & $48 \%$ & $51 \%$ & $53 \%$ \\
\hline & Increase due to climate change & $27 \%$ & $21 \%$ & $17 \%$ & $17 \%$ \\
\hline
\end{tabular}

climate scenario (results on geographical extent for other scenarios are similar). For absolute exposure, the largest number of people exposed are found in the Mekong Delta, the Red River Delta, and the Southeast Coast (Figs. 5, 6, and 7). But the relative exposure (that is, the percent of the district population which is exposed to floods) shows a larger spread (Figs. 8, 9, 10). Most areas in the country - including the North Central Coast and the Northeast - have high percentages of their populations residing in flood-prone areas (Fig. 8).

\section{Flood Exposure and Poverty}

To examine the question of how many poor people in Vietnam are exposed to flooding, we multiply the population exposure estimates by the district's poverty headcount rate (the percentage of people living below USD 1.25 per day), as calculated in (Lanjouw et al. 2013).

For a 25 -year historical flood, $30 \%$ of today's poor population is exposed. This number increases by between 16 and $28 \%$ given climate change impacts. For a 50 -year return period under a high climate scenario, $40 \%$ of today's poor people in Vietnam are exposed to flooding. For a 200-year return period under a high climate scenario, more than half of today's poor are exposed. Similar to the population analysis, the impact of climate change on the number of poor people exposed is evident. For instance, a 25-year event with high climate change impacts has the same exposure as a 200 -year historical event (at around $41 \%$ of poor people being exposed).

Based on the statistics provided in Table 4, there is no strong signal that poor people are more exposed than non-poor people, at the national level. However, this may not be the case in specific regions or within specific districts.

To examine which districts have a confluence of poverty and flood hazard, we classify both each district's poverty headcount rate and flood exposure into three categories: low, medium, and high. We create 3 quantiles for each. We examine both absolute and relative numbers, overlaying the number of poor and number of flood exposed, and the percentage of poor and percentage of flood exposed. The results suggest that areas of the Northern Mountains and the Mekong Delta exhibit districts with high flood and high poverty (darkest shade of brown in Fig. 11). The results are slightly different when comparing relative and absolute numbers. When using absolute (the number of poor and number of flood exposed) more areas of high flood and poverty are visible in the Mekong and Red River Delta, as well as along the eastern coasts. 

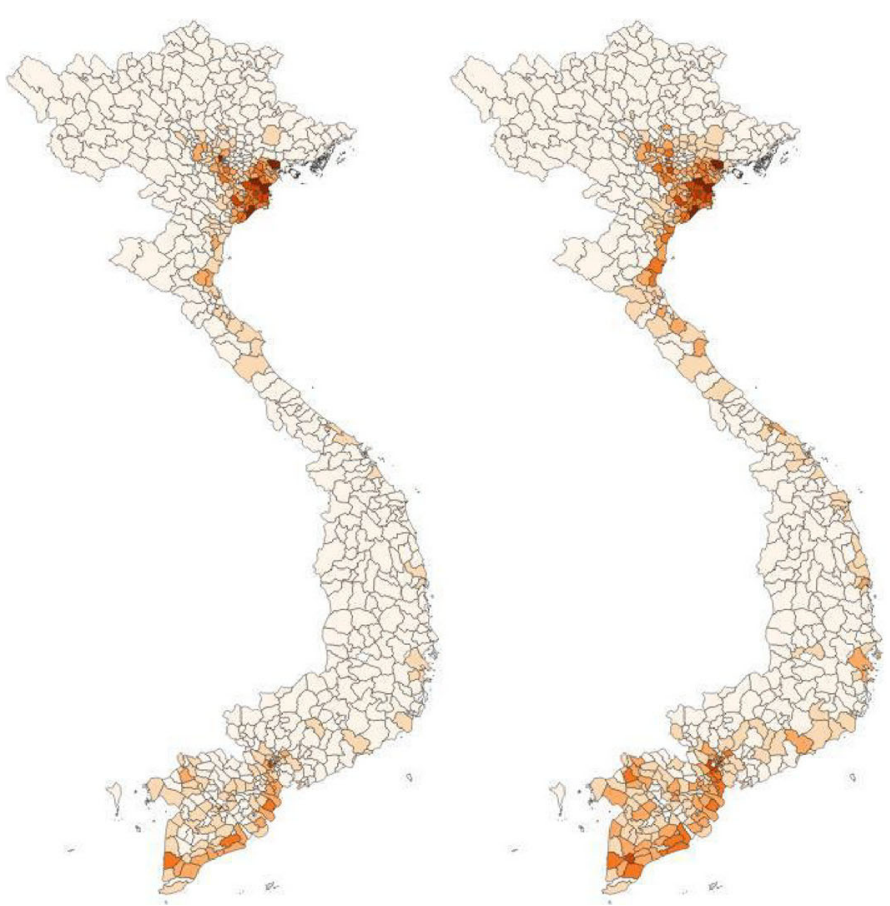

Total population exposed

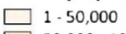

$50,000 \cdot 100,000$

$\square 100,000-150,000$

$150,000 \cdot 200,000$

- $200,000-250,000$

$250,000+$

Fig. 5 Absolute exposure at the district level (total number of people in a district exposed), for a 25-year historical flood (left) and a 25-year historical flood under high climate change (right)

However, even though not all of the poorest districts seem to face higher exposure to floods, it is important to remember that poor households and poor individuals within high exposure areas have generally higher vulnerability to the impact of floods. Further, it is very likely that within a district or city, the poorest are the most exposed to floods. We explore this dynamic at the local scale with a city-level analysis of HCMC.

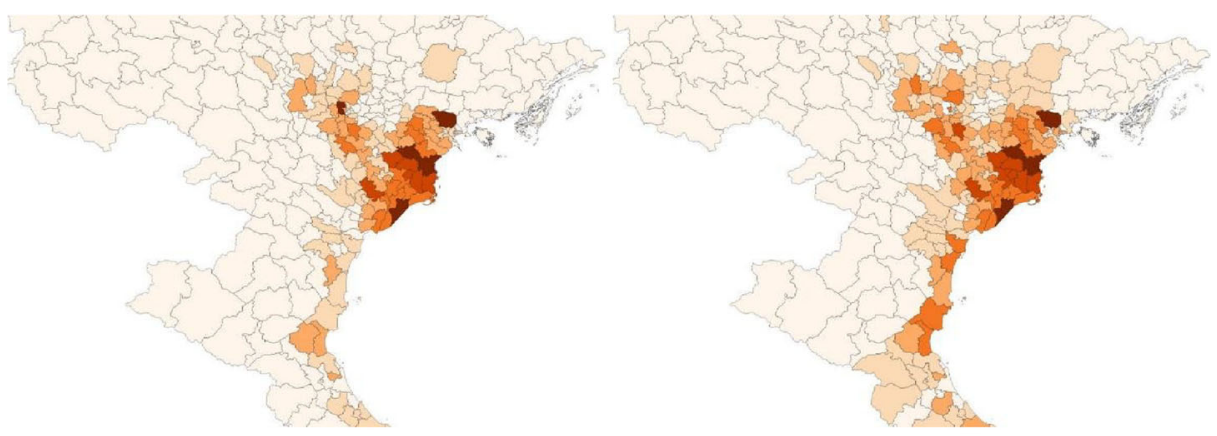

Total population exposed

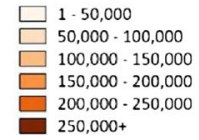

Fig. 6 Total population exposed in the Red River Delta for historical 25-year flood (left) and 25-year flood with high climate impacts (right) 


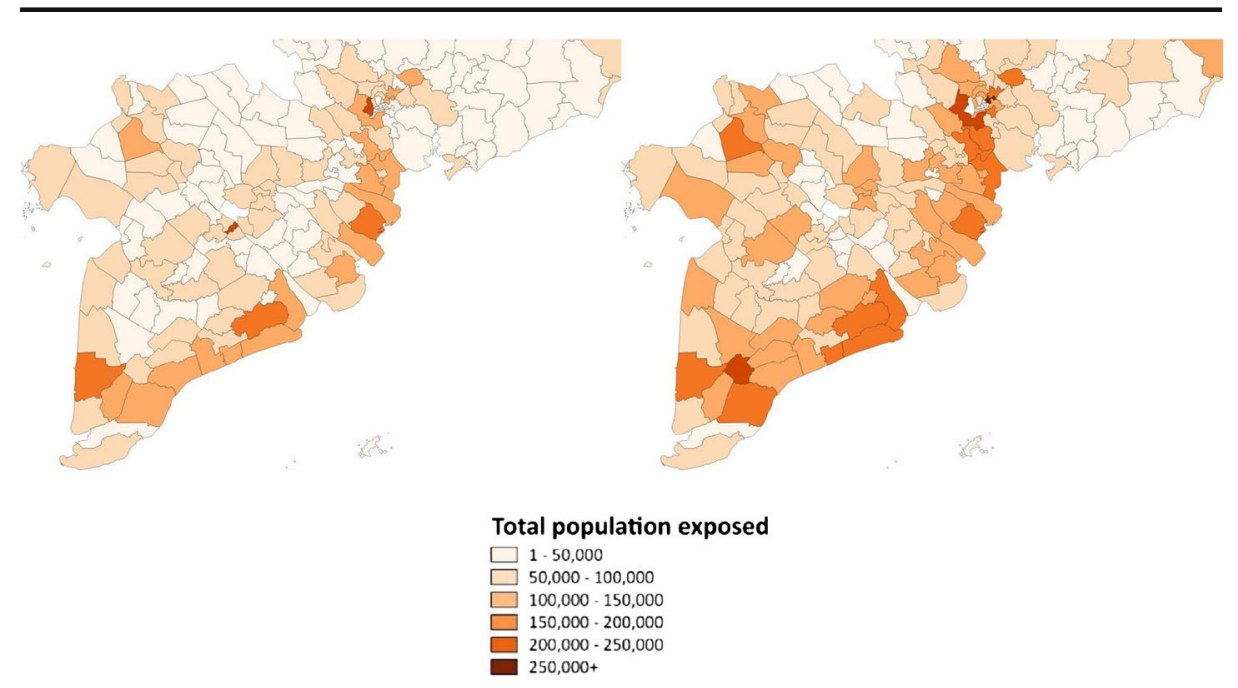

Fig. 7 Total population exposed in the Mekong for historical 25-year flood (left) and 25-year flood with high climate impacts (right)

\section{City-Level Analysis in HCMC for Poverty and Exposure to Floods}

While the relationship between poverty and exposure to floods may not be evident at the national or district level, at a more local scale and especially in urban areas, land and housing markets often push poorer people to settle in riskier areas (Lall and Deichmann
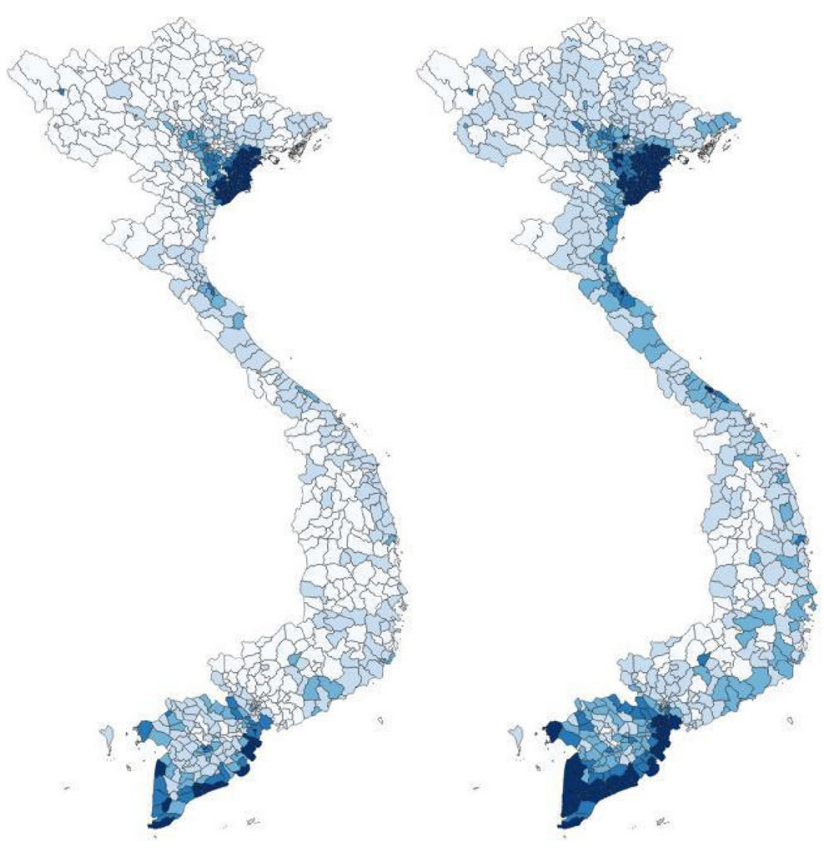

\section{Percent of population exposed}

$\square 0-20 \%$
$\square 20-40 \%$
$\square 0-60 \%$
$60-80 \%$
$80-99 \%$

Fig. 8 Relative exposure at the district level (percent of district population exposed), for a 25-year historical flood (left) and a 25-year flood under high climate change (right) 


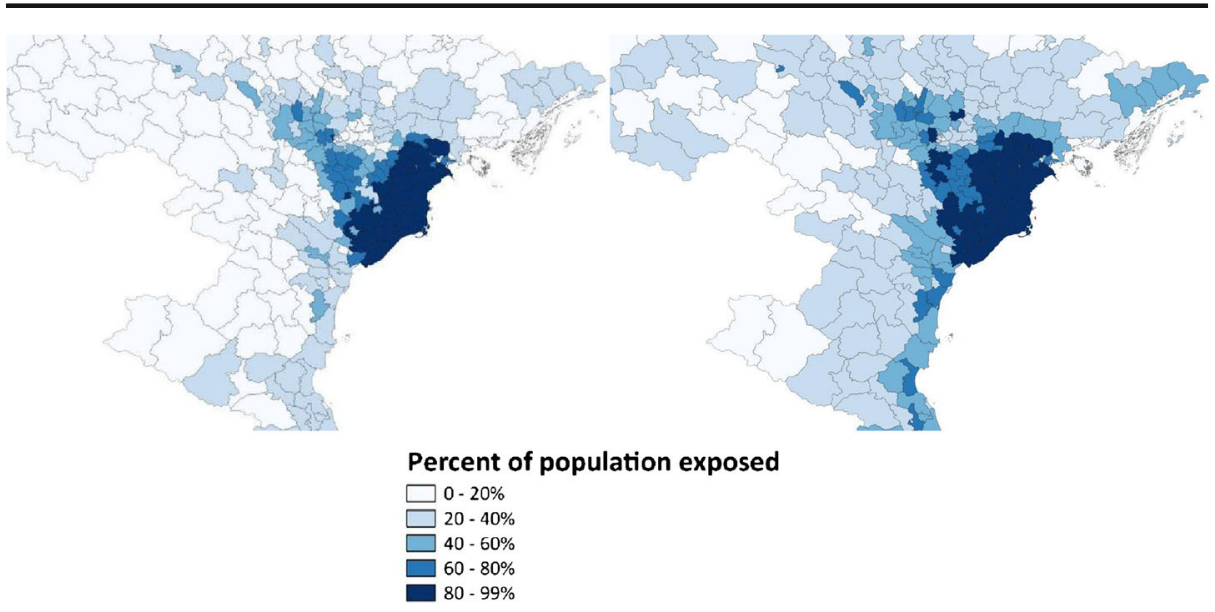

Fig. 9 Relative exposure in the Red River Delta for historical 25-year flood (left) and 25-year flood with high climate impacts (right)

2012). For instance, comparing exposure of poor people to average exposure, poor households are $71 \%$ more exposed to flooding in the Mithi River Basin in Mumbai, India (Hallegatte et al. 2016).

We examine these dynamics in HCMC, using high-resolution local-scale flood maps designed specifically for HCMC (Lasage et al. 2014) and a proxy for poverty using the spatial location of potential slums from the Platform for Urban Management and Analysis (PUMA) data set (World Bank 2015). The results we present below are for all districts in HCMC; results for only districts with slum areas are similar and thus not reported.

We find that a relatively high percentage of the potential slum areas are exposed to floods, ranging from $68.9 \%$ (for a 10-year return period) up to $83.3 \%$ (for a 1000 -year return period). When considering all urban areas of HCMC, exposure to flooding is lower: 63\% (for a 10-year
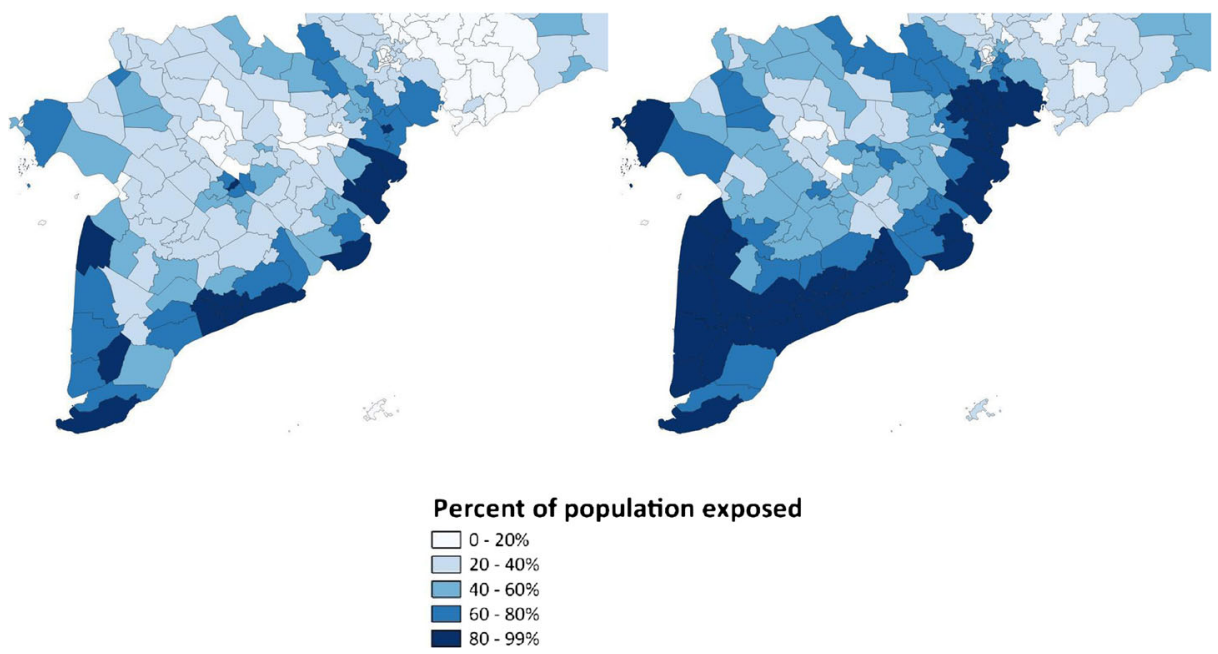

Fig. 10 Relative exposure in the Mekong Delta for historical 25-year flood (left) and 25-year flood with high climate impacts (right) 
Table 4 Number and percentage of poor exposed to floods in Vietnam, across the 16 flood hazard scenarios examined

\begin{tabular}{llcccc}
\hline \multirow{2}{*}{ Scenario } & Exposure & \multicolumn{2}{l}{ Return period } & & \\
\cline { 3 - 5 } & & & & & \\
& & 25 & 50 & 100 & 200 \\
\hline Historical & Estimated poor exposed (million) & 5.28 & 6.19 & 6.88 & 7.24 \\
& Percentage of today's poor & $30 \%$ & $35 \%$ & $39 \%$ & $41 \%$ \\
Low climate change & Estimated poor exposed (million) & 6.27 & 6.64 & 7.32 & 7.54 \\
& Percentage of today's poor & $35 \%$ & $37 \%$ & $41 \%$ & $42 \%$ \\
Medium climate change & Increase due to climate change & $16 \%$ & $7 \%$ & $6 \%$ & $4 \%$ \\
& Estimated poor exposed (million) & 6.80 & 7.16 & 7.69 & 8.00 \\
& Percentage of today's poor & $38 \%$ & $40 \%$ & $43 \%$ & $45 \%$ \\
High climate change & Increase due to climate change & $22 \%$ & $14 \%$ & $11 \%$ & $10 \%$ \\
& Estimated poor exposed (million) & 7.33 & 7.66 & 8.14 & 8.56 \\
& Percentage of today's poor & $41 \%$ & $43 \%$ & $46 \%$ & $48 \%$ \\
& Increase due to climate change & $28 \%$ & $19 \%$ & $16 \%$ & $15 \%$ \\
\hline
\end{tabular}

return period) up to $68.3 \%$ (for a 1000-year return period). A sea level rise of $30 \mathrm{~cm}$ increases the extent of flooded areas the most in slum areas and for a low-probability but recurrent flood (10-year flood). For a 10-year flood and looking only within slum areas, we find an increase in exposure of 15 percentage-points due to sea level rise, compared to a difference of 5.7

a

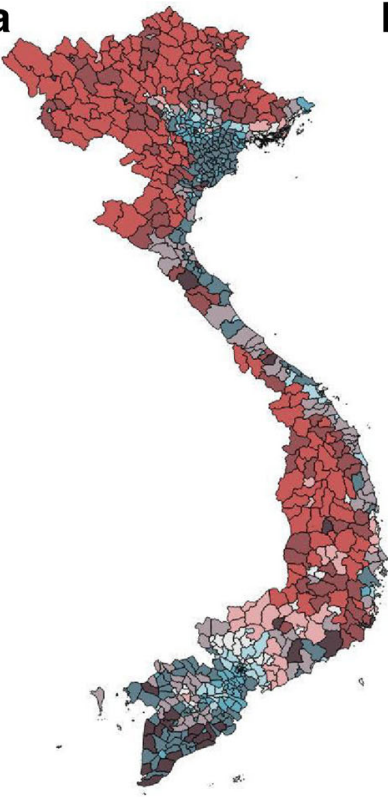

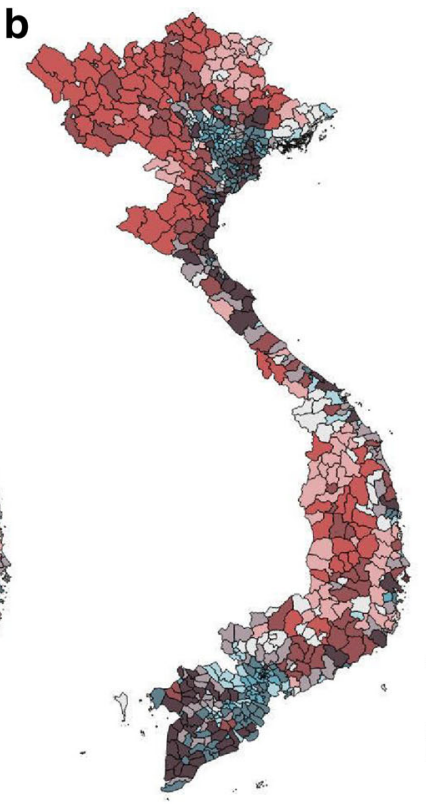
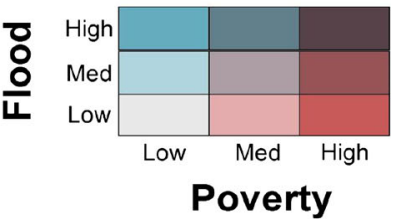

Fig. 11 Overlay of poverty and flood at the district level for the 25 year-return period flood with climate change. Map A shows relative exposure, overlaying the percent of poor and percent of population flooded, Map B shows the absolute exposure, overlaying the \# of poor and \# of population flooded. Bins: Map A, Poor, Relative (Low = 0-15\%, Med $=15-28 \%$, High = 28\%+). Bins: Map A, Flood Exposure, Relative $($ Low $=0-26 \%$, Med $=26-47 \%$, High $=47 \%+$ ). Bins: Map B, Poor, Absolute (Low =0-15,900, Med =15,900 - 31,000, High = 31,000+). Bins: Map B, Flood Exposure, Absolute (Low =0-27,000, Med =27,000 - 70,000, High = 70,000+) 


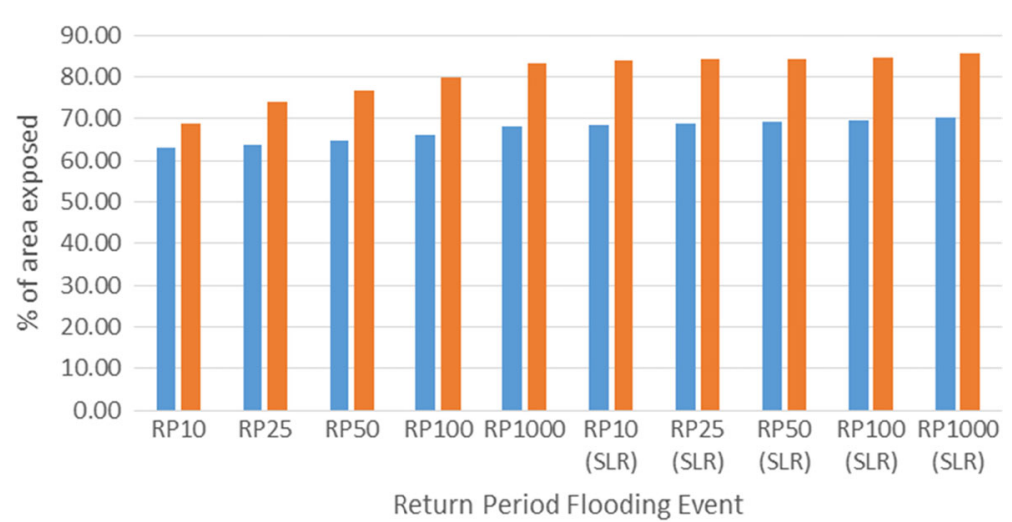

Within All urban areas Within Potential slum areas

Fig. 12 Slum areas tend to be more exposed than the average, across all flood scenarios. SLR means the scenario includes a $30 \mathrm{~cm}$ sea level rise due to climate change. RP denotes the flooding events with a particular return period (e.g. RP10 stands for a flooding event with a 10-year return period)

percentage-points when looking at the entire urban area of HCMC. These results, as presented in Fig. 12, suggest slum areas to be more exposed to floods (and changes in flooding due to climate change) than non-slum areas. ${ }^{7}$

\section{Discussion and Conclusion}

This paper conducts a stress-test and presents some initial findings on what exposure to floods looks like in Vietnam, how it may change under a changing climate, and whether poor people are relatively more exposed. Our main contributions are twofold: we first develop a state-ofthe-art model at high resolution to represent riverine and coastal flood hazard for Vietnam considering climate change. Second, we examine how exposure to floods differs based on socioeconomic characteristics, with an explicit focus on poverty.

Our results indicate that climate change is likely to increase the number of people exposed to floods, especially in the Mekong and Red River Deltas. For the same return period flood under current socioeconomic conditions, climate change may increase the number exposed to 38 to $46 \%$ of the population (an increase of 13-27\% above current exposure), depending on the severity of sea level rise. Regarding poverty and exposure, while we do not find evidence of a differential exposure at the national level, we find at the city level that poor people are relatively more exposed to floods. Within HCMC, potential slum areas are 10-20\% more exposed to floods compared to the rest of the city, with the exposure differential increasing with climate change.

Nevertheless, the findings presented in this paper should be interpreted considering a number of caveats.

While we use current and future flood data, we only use current population and poverty data, as reliably projecting these socioeconomic trends spatially into the future is almost impossible. Changes in these trends - among many other factors - can lower socioeconomic

\footnotetext{
${ }_{7}$ Disaggregated results per district, and results using depth as an indicator can be found in the online supplementary materials.
} 
vulnerability even as the climate change hazard increases (Hallegatte et al. 2016). Along these lines, while we examine which regions within Vietnam have the highest flood exposure, we do not examine the determinants of vulnerability (other than poverty). Recent analyses suggest that the Northwest, Central Highlands, and Mekong River Delta have the greatest socioeconomic vulnerability (World Bank 2010).

In the flood hazard maps developed for this paper, we assume no protection due to a lack of data and as a result the hazard maps present an upper bound of flood exposure. Work is currently ongoing to develop a global database of flood protection, and this information can be mobilized for future work (Scussolini et al. 2016). For the national-level analysis, flooded areas are defined as any area with inundation higher than 0 . We have not yet explored the depth dimension, although the flood hazard maps developed for this study allow for this potential in future work.

For the HCMC analysis, the location of the slum areas in the PUMA data set are mainly restricted to the old town. Furthermore, slum areas are often difficult to define (with PUMA only identifying potential slums) and the data we have likely does not capture all slum areas within HCMC. In terms of the hazard, the flood maps for HCMC show flood depth and extent from the river and from sea (when looking at the sea level rise scenario). Pluvial flooding and possible 'sink'-areas in the city are not taken into account. Moreover, the lowest return period we have flood maps for is not low, compared to what is experienced in the city. Some areas of HCMC are flooded every year. Since this analysis used a flood with a 10-year return period as the flooding scenario with the highest recurrence interval we were not able to capture the relative differences in exposure to these yearly/bi-annual flooding events (and we hypothesize that poor people are relatively more exposed to these types of flooding than the general population).

Despite these limitations, the analysis presented at the country and city-level can offer a number of points for discussion.

The findings of this paper suggest that climate change is likely to substantially increase the number of people exposed to flooding in the future. However, current planning approaches in Vietnam have not yet adequately taken climate change into account (IMHEN and UNDP 2015). For example, the city of Long Xuyen in the Mekong Delta has based its dike infrastructure around the city on historical floods levels only, with no inclusion of future climate changeinduced water levels, despite the poor performance of existing defenses to recent flooding events (World Bank 2016). Investments in climate-informed flood protection taken now reduce flood exposure, but can also save money in the long-run by reducing the amount spent on recovery and reconstruction for future floods. And while it is challenging to integrate into project planning, innovative approaches such as decision-making under uncertainty can support policy-makers to design flood projection with climate change in mind (Hallegatte et al. 2012).

This analysis also provides some insights into where to locate flood infrastructure investments when considering socioeconomic characteristics. Generally flood defenses are located in areas where the expected losses are high - which concentrates investments in areas with the highest property and asset values. However, as shown in his paper, socioeconomic considerations such as poverty are important for flood vulnerability. Such a system, prioritizing areas of asset accumulation, will not prioritize poorer places which inevitably have fewer assets. At the country-level, this paper finds that poverty and flood exposure overlap in specific districts of the Mekong Delta and the North Central Coast, which might warrant further attention.

At the city level, we find potential slum areas to be more exposed to floods in HCMC, and that the exposure differential increases with climate change. As a result, risk-sensitive land-use planning may be a priority to ensure development takes place in safer areas. Such planning might encourage development at the outskirts of the city, which are less prone to flood risk, 
and can be identified from the results of this paper. An important constraint is that for such development to be feasible, they should be paired with transportation investments, which maintain access to the city center where opportunities are presented (World Bank 2015).

Despite the potential of risk-sensitive land-use planning, resettlement is the major ex-ante hazard adaptation mechanism employed in Vietnam currently, especially in the Mekong Delta. While such policies can reduce exposure, policy design is critical to ensure the livelihoods of the poor are supported. For instance, surveys in Tan Chau district suggests the resettlement policy enacted in 2002 may have made households worse-off: inadequate financing resulted in households paying for their new settlements out-of-pocket; many households who were farmers and fishers did not have adequate land, transportation and market access, and inadequate livelihood support was provided to them (World Bank 2016). Where resettlement policies are enacted, it is imperative that such policies are paired with livelihood and financing support.

Beyond strategies to reduce exposure, other policy options to reduce vulnerability to improve households' ability to adapt may warrant increased attention. Strategies such as government subsidies for household-level flood protection (like raising of floors), improved financial inclusion, and better observation systems and early warning, and resilient agricultural practices can reduce the asset and income losses associated with floods (Hallegatte et al. 2016). When hit, targeted social protection (which can support the affected population quickly after a large flood) can hasten recovery (Hallegatte et al. 2016, Chapter 5). Such policy measures may be targeted in areas with higher future exposure (geographical targeting) as well as to individuals and households classified as poor and near poor who experience flooding (individual targeting). Areas such as the Northern Mountains have high poverty and are expected to experience an increase in flood exposure. While infrastructure protection can be costly in these remote and sparsely-populated areas, strategies to reduce vulnerability or improve the ability-to-adapt of households can reduce flood impacts.

The results of this paper provide an estimate of the potential exposure under climate change, including for poor people, and can suggest increased attention and investments be directed towards improving adaptive capacity. Future research on how to design such policies, and how to enable institutional framework conditions to enable private adaptive capacity may be a priority for future research.

Acknowledgements This Work Is Part of Programmatic Work on Climate Change, Poverty and Climate Resilience in Vietnam and Was Developed under the Oversight of Christophe Crepin and Stephane Hallegatte. The Authors Thank Abigail Baca, Christophe Crepin, Chandan Deuskar, Stephane Hallegatte, Stuart Hamilton, Pam McElwee, Madhu Raghunath, Maurice Rawlins, Ulf Narloch, Dzung Huy Nguyen, and Vo Quc Tuan for Valuable Comments and Feedback. Mook Bangalore Gratefully Acknowledges Financial Support by the Grantham Foundation for the Protection of the Environment and the UK's Economic and Social Research Council (ESRC)

Open Access This article is distributed under the terms of the Creative Commons Attribution 4.0 International License (http://creativecommons.org/licenses/by/4.0/), which permits unrestricted use, distribution, and reproduction in any medium, provided you give appropriate credit to the original author(s) and the source, provide a link to the Creative Commons license, and indicate if changes were made.

\section{References}

Adger N (1999) Social vulnerability to climate change and extremes in coastal Vietnam. World Dev 27(2):249269. https://doi.org/10.1016/S0305-750X(98)00136-3

Apel H, MartínezÂaTrepat O, Hung NN, Chinh DT, Merz `B, Dung NV (2016) Combined fluvial and pluvial urban flood hazard analysis: concept development and application to Can Tho city, Mekong Delta, Vietnam. Nat Hazards Earth Syst Sci 16:941-961. https://doi.org/10.5194/nhess-16-941-2016 
Barrett A, McIntosh R, Pritchard M, Hannan M, Alam Z, Marks M (2013) Asset Values: Why Are Some Households Doing Better than Others? Chars Livelihood Program

Ceola S, Laio F, Montanari A (2014) Satellite nighttime lights reveal increasing human exposure to floods worldwide. Geophys Res Lett 41(20):7184-7190. https://doi.org/10.1002/2014GL061859

Chinh DT, Dung NV, Gain AK, Kreibich H (2017) Flood loss models and risk analysis for private households in can Tho City. Vietnam Water 9:313

De Lay S (2011) Slums in Ho Chi Minh City, Vietnam. Global Cities 2011. http://hochiminhcity2011.jimdo. com/slums/

Del Valle, Alejandro et al. (2018) The Short-Term Economic Impact of Tropical Cyclones: Satellite Evidence from Guangdong Province. Econ Dis Climate Chang 1-11

DHI (2003) MIKE 11 - A Modelling System for Rivers and Channels. Short Introduction Tutorial. Water and Environment

Fay M (2005) The Urban Poor in Latin America. Directions in Development - General. The World Bank. http:/elibrary.worldbank.org/doi/book/10.1596/0-8213-6069-8

FIM (2013) Final Report, Volume 2, Integrated Flood Management Strategy. Ho Chi Minh City Flood and Inundation Management

Geographic Information Science and Technology (2015) Landscan Population Data. Oak Ridge National Laboratory

GFDRR (2015) Country Profile - Vietnam. https://www.gfdrr.org/sites/gfdrr/files/region/VN.pdf

Goeschl T, Managi S (2017) Public in-kind relief and private self-insurance. Econo Dis Clim Chang:1-19

Habitat for Humanity (2008) Mapping Urban Poverty in Ho Chi Minh City." http://content.yudu.com/Library/A1 gwji/MappingUrbanPovertyi/resources/8.htm

Hallegatte S, Shah A, Brown C, Lempert R, Gill S (2012) Investment Decision Making under Deep Uncertaintyapplication to Climate Change." World Bank Policy Research Working Paper, no. 6193. http://papers.ssrn. com/sol3/papers.cfm?abstract_id=2143067

Hallegatte S, Bangalore M, Bonzanigo L, Fay M, Kane T, Narloch U, Rozenberg J, Treguer D, Vogt-Schilb A (2016) Shock waves: managing the impacts of climate change on poverty. In: Climate change and development series. World Bank, Washington, DC

Hallegatte S, Vogt-Schilb A, Bangalore M, Rozenberg J (2017) Unbreakable: building the resilience of the poor in the face of natural disasters. In: Climate change and development series. World Bank, Washington, DC

Hirabayashi Y, Mahendran R, Koirala S, Konoshima L, Yamazaki D, Watanabe S et al (2013) Global flood risk under climate change. Nat Clim Chang 3(9):816-821

Horsley W (2004) Vietnam's Slum Dwellers. BBC News

Husby T, Hofkes M (2015) Loss Aversion on the Housing Market and Capitalisation of Flood Risk. http://www. webmeets.com/files/papers/eaere/2015/903/eaere_pt.pdf

IMHEN, and UNDP (2015) Summary for Policy Makers. Viet Nam Special Report on Managing the Risks of Extreme Events and Disasters to Advance Climate Change Adaptation [Trần Thục, Koos Neefjes, Tạ Thị Thanh Hương, Nguyễn Văn Thắng, Mai Trọng Nhuận, Lê Anh Tuấn, Lê Đình Thành, Huỳnh Thị Lan Hương, Võ Thanh Sơn, Nguyễn Thị Hiền Thuận]. Natural Resources and Environment Publishing House, Hanoi

Institute of Strategy and Policy on Natural Resources and Environment (2009) Viet Nam Assessment Report on Climate Change

IPCC (2007) Summary for Policymakers." In Climate Change 2007: Mitigation. Contribution of Working Group III to the Fourth Assessment Report of the Intergovernmental Panel on Climate Change, B. Metz, O.R. Davidson, P.R. Bosch, R. Dave, L.A. Meyer (eds). Cambridge University Press, Cambridge, UK and New York, USA. http://www.ipcc.ch/pdf/assessment-report/ar4/syr/ar4_syr_spm.pdf

IPCC (2014) Climate Change 2014: Impacts, Adaptation, and Vulnerability. Part B: Regional Aspects. Contribution of Working Group II to the Fifth Assessment Report of the Intergovernmental Panel on Climate Change [Barros, V.R., C.B. Field, D.J. Dokken, M.D. Mastrandrea, K.J. Mach, T.E. Bilir, M. Chatterjee, K.L. Ebi, Y.O. Estrada, R.C. Genova, B. Girma, E.S. Kissel, A.N. Levy, S. MacCracken, P.R. Mastrandrea, and L.L. White (eds.)]. Cambridge, United Kingdom and New York, NY, USA: Cambridge University Press

de Janvry, A., F. Finan, E. Sadoulet, and R. Vakis. 2006. “Can conditional cash transfer programs serve as safety nets in keeping children at school and from working when exposed to shocks?” J Dev Econ 79: 349-373

Jongman B, Hochrainer-Stigler S, Feyen L, Aerts JCJH, Mechler R, Botzen WJW, Bouwer LM, Pflug G, Rojas R, Ward PJ (2014) Increasing stress on disaster-risk finance due to large floods. Nat Clim Chang 4(4):264 268. https://doi.org/10.1038/nclimate2124

Karim ,A, Noy I (2014) Poverty and Natural Disasters: A Meta-Analysis. http://researcharchive.vuw.ac. nz/handle/10063/3234

Kim N (2012) How much more exposed are the poor to natural disasters? Global and regional measurement. Disasters 36(2):195-211. https://doi.org/10.1111/j.1467-7717.2011.01258.x 
Koks EE, Jongman B, Husby TG, Botzen WJ (2015) Combining hazard, exposure and social vulnerability to provide lessons for flood risk management. Environ Sci Pol 47:42-52

Lall SV, Deichmann U (2012) Density and disasters: economics of urban Hazard risk. World Bank Res Obs 27(1):74-105

Lanjouw P, Marra M, Nguyen C (2013) Vietnam's Evolving Poverty Map: Patterns and Implications for Policy. Policy Research Working Papers. The World Bank. http://elibrary.worldbank.org/doi/abs/10.1596/18139450-6355

Lasage R, Veldkamp TIE, de Moel H, Van TC, Phi HL, Vellinga P, Aerts JCJH (2014) Assessment of the effectiveness of flood adaptation strategies for HCMC. Nat Hazards Earth Syst Sci 14(6):1441-1457. https://doi.org/10.5194/nhess-14-1441-2014

Le Dang H et al (2014) Farmers' perceptions of climate variability and barriers to adaptation: lessons learned from an exploratory study in Vietnam. Mitig Adapt Strateg Glob Chang 19.5:531-548

Liao K-H, Le TA, Van Nguyen K (2016) Urban design principles for flood resilience: learning from the ecological wisdom of living with floods in the Vietnamese Mekong Delta. Landsc Urban Plan 155:69-78

McElwee P et al (2017) Flood vulnerability among rural households in the red River Delta of Vietnam: implications for future climate change risk and adaptation. Nat Hazards 86(1):465-492

Ministry of Natural Resources and Environment (2009) Climate Change, Sea Level Rise Scenarios for Vietnam

Patankar A (2015) The Exposure, Vulnerability and Adaptive Capacity of Households to Floods in Mumbai. World Bank Policy Research Working Paper No. 7481

PUMA (2013) Interim Report Version 1.0.” Platform for Urban Management and Analysis (PUMA) Software Development and Satellite Imagery Processing Consultants

Rozenberg J, Hallegatte S (2016). Modeling the impacts of climate change on future Vietnamese households: a micro-simulation approach

Scussolini, P., Aerts, J. C., Jongman, B., Bouwer, L. M., Winsemius, H. C., de Moel, H., \& Ward, P. J. (2016). FLOPROS: an evolving global database of flood protection standards. Nat Hazards Earth Syst Sci, 16(5), 1049-1061

Smith A, Freer J, Bates P, Sampson C (2014) Comparing ensemble projections of flooding against flood estimation by continuous simulation. J Hydrol 511:205-219

Thoai TQ et al (2018) Determinants of farmers' adaptation to climate change in agricultural production in the central region of Vietnam. Land Use Policy 70:224-231

Wing OE, Bates PD, Sampson CC, Smith AM, Johnson KA, Erickson TA (2017) Validation of a $30 \mathrm{~m}$ resolution flood hazard model of the conterminous United States. Water Resour Res 53(9):7968-7986

Winsemius H, Jongman B, Veldkamp T, Hallegatte S, Bangalore M, Ward PJ (2015) Disaster Risk, Climate Change, and Poverty: Assessing the Global Exposure of Poor People to Floods and Droughts. World Bank Policy Research Working Paper No. 7480

World Bank (2009) Reshaping Economic Geography”. World Development Report

World Bank (2010) Economics of Adaptation to Climate Change in Vietnam

World Bank (2014) Turn Down the Heat: Climate Extremes, Regional Impacts, and the Case for Resilience

World Bank (2015) Platform for Urban Management and Analysis.” http://puma.worldbank.org/

World Bank (2016) Climate Change and Poverty in Vietnam. World Bank Internal Document

World Bank, and GFDRR (2011) Vulnerability, Risk Reduction, and Adaptation to Climate Change - Vietnam

World Bank, Australian AID (2014) 'WHERE ARE WE DURING FLOODING?' A Qualitative Assessment of Poverty and Social Impacts of Flooding in Selected Neighborhoods of HCMC 